\title{
Papers
}

Explorations into Children's Literature

\section{No traveller returns: the liminal world as ordeal and quest in contemporary young adult afterlife fiction}

\author{
Sophie Masson - University of New England
}

\begin{abstract}
In recent years, fiction specifically set in or about the afterlife has become a popular, critically acclaimed subgenre within contemporary fiction for young adults. One of the distinguishing aspects of young adult afterlife fiction is its detailed portrayal of an alien afterworld in which characters find themselves. Whilst reminiscent of the world-building of high or quest fantasy, afterworlds in young adult afterlife fiction have a distinctively different quality, and that is an emphasis on liminality. Afterlife landscapes exhibit many strange, treacherous qualities. They are never quite what they seem, and this sense of a continually shifting multiplicity is part of the destabilisation experienced by the characters in the liminal world of the afterlife. Inspired by traditional but diverse images of afterlife, afterworld settings also incorporate aspects of dream-space as well as of the real, material world left behind by the characters. The uncanny world of the dead is not just background in these novels, but crucial to the development of narrative and character.

In this paper, it is argued that the concept of liminal place is at the core of the central ordeal and quest of characters in young adult afterlife fiction. It explores how authors have constructed the individual settings of their fictional afterworlds and examines the significance of the liminal nature of the afterworlds depicted in young adult afterlife fiction.
\end{abstract}

Keywords: afterlife fiction, liminality, afterworlds, fictional settings

\section{Introduction}

Afterlife fiction is a recent sub-genre of the wider genre of speculative fiction, which encompasses fantasy in its various manifestations, such as high, urban and portal fantasy, as well as science fiction, paranormal fiction, horror fiction, and alternative history. Although the journey to the afterworld has featured as a consistent if uncommon theme in religious and mythological works and classic narratives, such as in Dante's Divine Comedy, 
contemporary afterlife fiction has arisen within a cultural context of renewed interest, including in screen narratives, in the creative possibilities of afterlife beliefs and concepts from diverse religious and mythological traditions. In afterlife fiction, whether for adults or young adults, the dead are not a danger to the living world, unlike in related sub-genres such as ghost, vampire or zombie fiction; the afterlife is the major, not a minor, theme; characters are either dead or in a state between life and death, such as a coma; narratives begin with death, not end in it; and character development is centred around the struggle to reconcile pre-death identities with afterlife transformations in an alien world, the world beyond death. Despite inspirations drawn from religious or mythological contexts, afterlife fiction does not generally have a religious purpose, though it may have a philosophical element: the post-death theme is most of all a narrative, creative choice. In young adult afterlife fiction, adventure is more central than in adult afterlife fiction, and moreover there is a detailed portrayal of the alien afterworld, its settlements and landscapes, an element not usually found in adult afterlife fiction, where the afterworld itself is accorded less importance than other narrative concerns. Whilst reminiscent of the world-building of high or quest fantasy, afterworlds in young adult afterlife fiction have a distinctively different quality, and that is an emphasis on liminality.

In this paper, I argue that the concept of liminal place is at the core of the central ordeal and quest of characters in young adult afterlife fiction. Rather than providing a detailed analysis of an individual text or texts, the aim of the paper is to provide an overview of the way multiple texts have treated place and landscape in order to achieve their narrative purpose. This is undertaken firstly through a survey of the concept of liminality and ordeal and quest motifs, and how these apply to young adult afterlife fiction. An examination of how authors have constructed their individual afterworlds follows, including an exploration of the topoi, or landscape types and features, which commonly occur in these afterworlds, as well as the nature of settlements there. 


\section{Liminality and young adult afterlife fiction}

In The Forest of Symbols (1967) his seminal work on the concept of liminality to describe the in-between state of participants in traditional rites of passage and initiations, cultural anthropologist Victor Turner noted that the person undergoing the subject of passage ritual is, structurally if not physically, 'invisible. (Turner, 1967). This means that in this state they have no status in any societal or even existential structure they previously belonged in. As Dag Øistein Endsjø described it: 'Thus, all the usual social states of gender, age, hierarchy, as well as even more basic opposites such as human versus divine, human versus animal, and dead versus alive, may be negated and reverted in the liminal state' (Endsjø, 2000, p.354) He goes on to equate the liminal state of rites of passage with the journeys into the afterworld of Ancient Greek mythical heroes such as Herakles and Odysseus, who venture into the liminal territory of Hades with a specific purpose.

This concept of liminality may usefully be extended to illuminate young adult afterlife fiction, where characters are not only structurally but also physically invisible, at least in terms of the living. Furthermore, I would argue that the afterworld, with its ambiguous, disorienting and shifting landscapes, represents in and of itself both the characters' ordeal as they attempt to navigate the culture shock of finding themselves in an alien world, and their quest to reconcile pre-death identities with afterlife transformations. They are themselves in liminal states, just like the place they find themselves in. In Language and Ideology in Children's Fiction, John Stephens proposes that the depiction of a frontier landscape in young adult historical fiction expresses both an extension of the people who choose to inhabit it, and an adversary that they must either overcome or come to terms with. Similarly, characters in young adult afterlife fiction may be seen as inhabiting frontier territory: however in this case there is no choice and, as an adversary, the afterworld offers a third resolution which is neither mastery or acceptance, but rather transformation.

If, as Anthony Eaton proposes, young adult fiction can be looked at in terms of liminality as a 'threshold' rather than as a 'transitional' literature, (Eaton, 2013) then young adult afterlife fiction has a double liminality. Though it appears popular with readers and has garnered 
awards, especially in the United States, it has received little sustained critical attention, unlike adult afterlife fiction which is extensively explored in Alice Bennett's book, Afterlife and Narrative in Contemporary Fiction (2012). Bennett does examine the afterlife theme in Philip Pullman's His Dark Materials, but this work cannot be defined as afterlife fiction per se. A brief examination of the afterlife theme in several Australian young adult novels is contained in Dale Kathryn Lowe's 2016 thesis, Postsecular spirituality in Australian YA Fiction, but none of the books she surveys are afterlife fiction as defined in the first paragraph of this article. Similarly, Patty Campbell examines the afterlife theme in a chapter in her book, Spirituality in YA Fiction: The Last Taboo (2015), but as she concludes that afterlife fiction per se is not concerned with spiritual matters, she only surveys these novels briefly before looking at a wider range of young adult novels. Furthermore, young adult afterlife fiction's emphasis on the liminal nature of an afterworld which mirrors the characters' own liminality, makes it difficult to place the narratives within an ideological framework, unless that framework is construed as being a deliberate blurring of all structural boundaries.

The works examined in this paper have all been published since 2003, with the sole exception being Astrid Lindgren's novel The Brothers Lionheart (1973), included briefly as a contrast to the contemporary works. All the contemporary works except for one, Margo Lanagan's short story Under Hell, over Heaven (2006), are novels. All except for Kinga Wyrzykowska's Memor: le monde d'après (2015), which I read in the original French, are English-language works, published in either the US, UK, Australia or Canada. All the works are set in or are about the afterlife, which is both the driver of the plot and a major theme in the narrative. These works have been chosen both for their detailed evocation of the afterworld, and creative exploration of how place in that world is an integral part of characters' ordeal and quest.

\section{The gathering spot}


In literary terms, setting may be distinguished from place by nothing that, classically, setting includes both the spatial and temporal dimensions (and usually, cultural as well) contained within the particular world of the narrative, while place refers to the spatial only, whether within the natural or human world. Novelist Eudora Welty, in her essay Place in Fiction (1955), made a strong case for the crucial importance of place in fiction as 'the named, identified, concrete, exact and exacting, and therefore credible, gathering spot of all that has been felt, is about to be experienced, in the novel's progress' (Welty, 1955, p.231.) Welty is referring specifically to the realist adult literary novel, concerned with 'the local, the "real" the present, the ordinary day-to-day of human experience' but even within the framework of mimetic realism, place in fiction is never just 'ordinary' or factual. Indeed, it could be argued that place itself, in reality, is never just factual, as the work of cultural geographers and landscape historians such as Jacquetta IHawkes, Carl Otwin Sauer, and W.G. Hoskins has shown. Real places, including in the natural world, are themselves imbued with stories and meanings built up over millenia, and rather than being unchanging, these meanings shift and transform constantly, so it is not surprising that in fiction, place is never static, and is not just tied to the purely spatial. Leonard Kriegel, who describes a sense of place as haunting writers because it is an 'imaginary physical configuration', goes on to observe:

Like the North and South Pole on a Mercator map, imagination's literary projections are expansive and blown out of proportion. A more exact map threatens to skew a writer's imaginative sense of place by distorting it to the hard lines of fact. Writers are not interested in "real" geography, because real geography has nothing to do with how literary maps allow them to distort the places one tries to capture in the pursuit of narrative reality. (Kriegel, 1994, p.604)

When we turn to contemporary young adult fiction, this 'distortion' appears to echo its target readership's disconnected sense of place. Gerrit W.Bleeker and Barbara S.Bleeker, looking at a range of realist young adult fiction, propose that for many teens, especially 
urban teens, a disconnection with place has become normal, leading to a more disorienting lived experience. They argue that instead of clearly anchoring teens within family, community, and institutions like schools to forge a coherent identity, fluid spaces such as shopping malls engender feelings of disconnection and alienation. Young adult fiction, they go on to argue, mirrors those feelings (Bleeker and Bleeker, 2008.) This may be an overstatement of the contemporary situation both for young people's lived experience and in young adult fiction, but it is still a useful observation, and not only for mimetic realism, whose aim is to recreate reality as far as possible.

As noted earlier, world-building, the creation of detailed unfamiliar imaginary worlds, is a characteristic of fantasy, especially but not exclusively high fantasy. Maria Nikolajeva, who uses the literary term 'xenotopia' or strange place, to describe them, observes that creating a xenotopia is:

...a powerful defamiliarisation device. In a xenotopic setting, readers are vulnerable, because they cannot anticipate the rules of this fictional world, including laws of nature, social structures, or physical abilities of its inhabitants (Nikolajeva, 2014.)

Afterlife fiction employs the xenotopic trope, of course, but further destabilises reader expectations by the fact that, as Alice Bennett proposes, the worlds created;

....are at once familiar and fantastic. They fall somewhere between the worlds of the fantasy novel, which offers a completely unfamiliar geography, and the known landscapes of famous cities like London and New York (Bennett, 2012, p.168.)

This feature is not unique to the afterlife sub-genre, but is present in speculative fiction generally. However, in afterlife fiction the twist is that the unfamiliar world is uncanny and unknowable to the living: and death, whose function in narrative is generally a dramatic end 
to a character's quest or purpose, is here the conduit to its beginning. The familiar is left far behind as the uncanny world, the xenotopia of the afterlife, takes over as the meaningful 'gathering spot' of all that is felt and experienced by the characters. This xenotopia is destabilising to the reader but also to the main characters, who are flung without ceremony or warning into a world in which they have few if any bearings, where all their previous assumptions mean little, and where they must endure many ordeals to fulfil a quest they often barely understand.

\section{Quest and ordeal in a liminal world}

It is useful here to revisit the concept of the classic quest. With its attendant motif of ordeal, it is perhaps the oldest in literature, forming the core of ancient narratives such as The Epic of Gilgamesh and The Odyssey. Christine Arkinstall argues that in these texts, as much as in contemporary literature, the point of the quest is not just about finding things or people or discovering secrets. It also symbolises the pursuit and achievement of a sense of personal identity' (Arkinstall,1993, p.39.) High or quest fantasy, such as JRR Tolkien's The Lord of the Rings, follows this pattern closely and is often found in literature for young people, as observed by Maria Nikolajeva: 'the quest is by far the most important motif in children's literature, especially if we treat it more broadly, not limiting it to the search for a person or object but also including the quest for identity' (Nikolajeva, 2005, p.82.) In the narrative pattern famously described by Joseph Campbell, known as 'The Hero's Journey', and encapsulated by John Dowell, the quest comprises several distinct elements and stage: the ordinary world; the call to adventure; refusal of the quest; accepting the call/mentors; crossing the threshold into a special world; tests, allies and enemies; supreme ordeal; pursuit into ordinary world; resurrection and reward; return with the elixir/restoring the world (Dowell, 2012.)

In young adult afterlife fiction, these stages may be present but often subverted and transformed, in keeping with this sub-genre's emphasis on the liminal and ambiguous rather than the structured and classic. There is no preparation, call or mentors at the start, though 
occasionally, once a character is in in the afterlife a mentor or guide may be present for part of the narrative, as for example in Lynnette Lounsbury's Afterworld (2013) and Kinga Wyrzykowska's Memor. Furthermore, the 'hero's journey' concept presupposes an element of choice: despite initial reluctance, the hero will choose to follow the call. However, in most afterlife fiction, there is no choice, and no possibility of reluctance, refusal or indeed acceptance: it could be said that unexpected death is the call to adventure, but it is an unavoidable, enforced adventure. There are some narratives which include an element of choice-for instance, Yangsze Choo's The Ghost Bride (2013) and Memor--but even in these narratives, the characters who journey into the afterlife must do so because otherwise there will be disastrous consequences for themselves or others.

In some of the novels, one or more of the central characters may return to the living world with an 'elixir' of knowledge obtained through the ordeals they endured in their quest in the afterlife. However, in most, they do not return, as in the classic quest story, but stay in the liminal world where they will inevitably transform in one way or the other. In Neal Shusterman's The Skinjacker Trilogy (2006-2011), both outcomes happen: one of the two central characters, Allie, returns to the living world at the end, whilst the other, Nick, stays in the world of the dead.

This diversity of interpretation means that the classic 'hero's journey' pattern is not necessarily a template for the theme of the quest as evinced in young adult afterlife fiction. Though it shares with general young adult fiction a central concern with personal identity, the quest in afterlife fiction is sharpened by the fact that crossing the barrier of death brings in its wake a serious psychological crisis for the central characters. In this way, it can be compared, as suggested in the introduction, to the initiate's experience in rites of passage, yet in the afterlife it is not just pre-existing states of being, but actual bodies that must be left behind as well, mostly forever. Young adult afterlife fiction is neither classic initiation nor classic hero's quest; it is the ambiguity of these afterworlds that makes the quest so difficult, and the ordeal so marked. Terri Doughty, in reference to Charles de Lint's young adult fantasy fiction, writes that; 
...identity formation certainly occurs in the world of mundane reality, but for de Lint such processes are highlighted in liminal spaces...blending the fantastic and the realistic, as in de Lint's work, creates a continuing state of duality, or multiplicity, a non-material space of in-betweenness. (Doughty, 2006, p.157)

Doughty's observation goes to the heart of the meaning of place in young adult afterlife fiction. Afterlife worlds as depicted in these works, such as the territories of Everlost in The Skinjacker Trilogy, the Plains of the Dead in The Ghost Bride, and the hybrid landscapes of Afterworld, are not inspired by the absolutist territories of heaven and hell, which are fixed, eternal, and thus problematic for the purposes of narrative and character development. Instead, they are liminal places which exist in a liminal time: between eternity and mortal time. This temporal dimension may usefully be referred to as 'angel time', a notion first proposed by $13^{\text {th }}$ century theologian and philosopher Thomas Aquinas, and adapted for literary theory by Frank Kermode in The Sense of An Ending (1967), where he used it as a metaphor for how time passes in fiction. This challenging sense of a continually shifting multiplicity is experienced by the characters in a place which could be seen as the ultimate in non-material space.

Alice Bennett observes that:

\begin{abstract}
Afterlife fiction makes repeated use of readers' recollection of similar worlds: worlds in which the physical laws of time and space are abandoned, where there is a causal or karmic logic to punishment and reward, where certain specific and familiar architectures and landscapes-rivers, plains, fields, camps, schools, hotels, cities-appear again and again (Bennett, p.177.)
\end{abstract}

What Bennett is articulating here is the way in which these afterworlds may resonate with readers in unexpected ways, from previous reading, cultural and religious knowledge, and lived experience. Afterlife landscapes may echo traditional images of liminal places found in 
religious belief, such as Purgatory, the Bardo, Limbo and Hades, but also include elements which may be found in that liminal territory we all know: the world of dreams. In dreams, time passes differently, identities are confused, things, people and animals shape-shift, landscapes, whether natural or built, rapidly change, events happen without explanation, and the prevailing atmosphere may shift in an instant from cosy to terrifying, sad to grotesque.

\section{The return of Purgatory}

Traditional liminal spaces like Purgatory and the Bardo are useful sources for afterworld settings because - unlike the fixed end-points of Heaven or Hell, where time and fate are static - there are still possibilities for personal agency and thus, narrative development. In Catholic doctrine, even after death a person's ultimate fate is still undetermined if they are thought to be in Purgatory. This belief, which is ancient but first formally proclaimed as doctrine in 1438, holds that through serious ordeals of suffering, as well as the prayers of living relatives, departed souls can embark on a quest to redeem their sins and reach Heaven at last. In medieval times, this was also supplemented by the now-extinct practice of indulgences, where a person could buy themselves years off an assumed purgatorial sentence. The existence of Purgatory as a liminal place to expiate one's sins was denied by Protestant reformers, but continues as a current doctrine of the Catholic Church (Catechism of the Catholic Church).

In the Buddhist Bardo, a similarly liminal space, souls also have the opportunity to continue to shape their own destiny through transformation, but were also subject to many dangers. In the Chinese Daoist/Buddhist equivalent, families can also help to buy their dead relatives' passage from the in-between territories towards the Courts of Judgement and final bliss in the heavenly realms.

Though these places are important as inspirations in young adult afterlife fiction, however, they are not used in a religious sense, but rather for their narrative and creative possibilities 
as unusual fantastical settings. Moreover, they also inhabit a much more ambiguous space in traditional religious belief than that allocated to the diverse manifestations of Heaven and Hell, which are closely tied to the presence of gods and devils. Just as in Ancient Greek myth the gods are absent from Hades, so the Christian Purgatory is notable for the absence or at least the invisibility of God to the souls there, adding to their suffering. Similarly, in the Daoist/Buddhist afterlife, heavenly beings are absent from the in-between territories where the dead must wander and earn their release before being able to go further. This traditional absence of supreme sacred beings from liminal afterlife territories means that these liminal afterlife territories may be less firmly tied to notions of the sacred per se and thus may be seen as more approachable by writers. However, it is still notable that with one exception, Lounsbury's Afterworld, and unlike in religious and classical narratives, the young adult afterlife fiction examined in this paper does not contain overt references to gods or indeed devil figures and their place in the meaning of characters' ordeal. Lounsbury's novel has both God and Devil figures - known as the Awe and Deora respectively - and they both manifest as female, but though they exist and the main character Dom meets each of them, they are not prime actors in the narrative.

In traditional depictions of purgatorial worlds, the inhospitable, dangerous nature of the landscape a soul must traverse was not only the tormentor, but the tormented: in other words, it functioned not only as an aspect of external punishment, but of internal suffering. In young adult afterlife fiction, this aspect is maintained, though it is rarely depicted in the same way as in classic religious texts and paintings, where fire is a common feature and suffering is of a strongly physical nature. An exception is found in Margo Lanagan's short story, Under Hell, Over Heaven, an evocation of the guide trope in which four emotionless teenagers take redeemed and damned souls to their respective destinations of Heaven and Hell, traversing the territory of the 'Outer' as the purgatorial world is called in this story. With the implication that this arduous job is the teenagers' own penance, the story depicts the world of the Outer as colourless and indistinct, precariously poised between the fiery horrors of Hell's Gate above, with its sulphurous stink and superheated machinery, and the 'powdery shimmer' and sweet overheard music of the bright realm of the 'Eternal 
Benediction', or Heaven, below. The bleak landscape represents the hopeless situation of the protagonists, which, unusually for this sub-genre, appears to propose that the ordeal will have no end, the quest will be forever unfulfilled, and there will be no possibility for transformation at the end:

The Outer had her; it walled the thought she was reaching for in fog, embedded the feeling in cloud; it clumsied her toes and fingers and all her finer faculties and left her with only this, the barest inclination to keep moving, in the direction that felt like forward, but might turn out to be never to be forward, or backward, or any way, anywhere, ever. (Lanagan, p. 140)

In Ferryman (2013), Claire McFall does something similar in early scenes, the afterworld being a wasteland reminiscent of a cross between Purgatory and Hades, a bleakness echoed in a different key in Patrick Ness' dystopian More Than This (2013). Meanwhile The Ghost Bride depicts a desolate territory anchored in Daoist/Buddhist beliefs, and in Everlost (2006) Neal Shusterman evokes a traditional afterworld motif in his depiction of treacherous patches of territory where a 'Greensoul', or the newly arrived dead, may be lost forever. Not all young adult afterlife novels are set in a purgatorially-inspired afterworld, however: for instance, in Gabrielle Zevin's Elsewhere (2007), the afterworld is a sunny suburban holding place on the way to rebirth. In Memor, the afterlife is complete, comprising several planets. Not only is there no 'in between' purgatorial place, there are also no extremes, that is, no heaven and no hell. And in an early precursor to the contemporary novels, Astrid Lindgren's The Brothers Lionheart (1973), the post-death afterworld of Nangiyala is a place of 'camp-fires and sagas', which is reminiscent of the world of CS Lewis' Narnia: a world outside ours, yet not liminal in its structures, but solid in all respects. Place in this novel is not implicated in the ordeal and quest of the brothers: it is, instead, a comfort to them, placing them in a familiar yet enhanced environment better than the imperfect living one they had left behind. It is as though they had become characters in a beloved story, which they understand instinctively, in marked contrast to the contemporary novels, which are focussed on the confusion, fear and disorientation of characters thrust into an alien world. 


\section{Landscapes and settlements in young adult afterlife fiction}

In her book, Landscape in Children's Literature, which examines in detail the landscapes in Susan Cooper's The Dark is Rising fantasy series, Jane Suzanne Carroll draws on the discipline of landscape history, and more particularly, topoanalysis, to explore the meaning of place within the series. Topoanalysis is a tool used by landscape historians to examine the symbolic and cultural meanings of topological landscape features such as mountains, rocks, rivers, caves, as these meanings have developed through the centuries. Carroll expands this into literary analysis, stating, ' Like real environments, literary landscapes are composed of a series of identifiable topological commonplaces-topoi-and the literary representations of such elements conform with traditional, morphological forms which make use of the same physical features and symbolic functions and support the same kind of narrative action' (Carroll, 2011, p.3.) She identifies four such 'topoi' : the sanctuary topos, the green topos, the roadway topos, and the lapsed topos. Within each topos are sub-topos, often contrasting: for instance, the green topos includes garden at one end, wilderness at the other, while the roadway topos includes a forest path at one end and an urban street at the other. In this section, I have adapted her concept to propose three main topoi for the places and landscapes of young adult afterlife fiction. These are: the portal topos; the water topos; and the wasteland topos. All are all liminal places in themselves, in a liminal world.

The portal topos includes all the entry-places to the afterworld, once the central character or characters have embarked on their journey beyond death. They include a cruise-ship somewhere out at sea in Elsewhere; the shore of a lake, in Afterworld; an abandoned house, in More than This; a tunnel, in Ferryman. Even those portals which do not at first glance appear to be obviously liminal, such as the woods which give entry to the world of Everlost, the shadow-street in The Ghost Bride, which is like a ghostly copy of the real-world street, or the glass room full of photographs in Memor, are not quite what they should be: they exist uneasily, fading at the edges, neither here nor there.

These portals offer the first clue to the ambiguous nature of the world beyond, and function as a warning to the characters, and by extension, to the reader: not 'abandon all hope all ye 
who enter here,' but rather, 'abandon all assumptions.' These are the assumptions of the character's existence prior to death: whether those be about identity, relationships, action, or place. No matter how confident a character might be in their personal and cultural identity in life, in the afterlife they have few if any reference points, and the portal is their first introduction to what will be a continuing aspect of their ordeal.

The water topos includes rivers, streams, wells, lakes, and the sea, which frequently make an appearance in young adult afterlife fiction. This is not surprising, as bodies of water are associated not only with journeys, but with the world of the dead in many mythologies. These include, amongst many others, Charon the ferryman taking souls across the River Styx; Celtic belief that the afterlife was reached through water; the Egyptian god of the dead and the afterlife, Osiris, closely associated with the River Nile; and the Russian myth of the rusalka, ghosts of girls who haunt streams, luring young men to their deaths. In addition, in literature and symbolism the world over, and throughout time, water has been one of the most enduring representations of the dualities of life/death, conscious/unconscious and creation/destruction. As noted by Carl Jung, water may also represent rebirth or transformation, and this aspect of the water topos certainly features in young adult afterlife fiction, where bodies of water are often settings for change and discovery. For example, the lake in Afterworld is not only a portal for the main character Dom, but also where later he meets his hitherto unknown father; the sea in Everlost marks not only danger but also radical change for several of the main characters; and the 'river of life' in Elsewhere is a conduit to reincarnation.

The spaces where land and water meet, such as lakeshores, riverbanks and beaches, are also often found in the settings of young adult afterlife fiction and may also be included in this topos: liminal spaces that are constantly shifting and changing, where boundaries are unclear and implied as much by the difficulty of categorisation as by actual physical features. Following the water topos is what might be called the wasteland topos, which includes heathlands, moors and swamps, as well as abandoned urban areas. Originating in myth and legend, the concept of the Waste Land-a barren, uninhabited and treacherous place-is 
commonly found in literature, including in children's literature. John Stephens has observed that the wasteland is often a symbolic site, 'functioning as a gateway for physical and emotional transitions' (Language and Ideology in Children's Fiction, p. 174.) Uninhabited, unfarmed and difficult to traverse, especially in the past, heathlands, moors and swamps are at one end of the wasteland topos in young adult afterlife fiction. Traditionally, they have been seen as in-between places, unpredictable, dangerous and disorienting, yet also possible paths to escape, knowledge, and eventual redemption. In Gothic and Romantic fiction, for instance, they appear as loci for crucial scenes: such as, for example, Jane's flight across the moors in Charlotte Bronte's Jane Eyre. In young adult afterlife fiction, they are important sites for ordeals leading to transformation, for instance, in Ferryman, where the afterworld landscape is almost entirely heath, moor and swamp, dotted with the occasional rudimentary house where the main character Dylan and her apparently supernatural 'ferryman' or guide, Tristan, must take shelter from the demons and lost souls which haunt these wastelands at fall of night. A treacherous lake is also a feature of this afterworld landscape, which in its oppressive and unpredictable aspects, perfectly captures Dylan's state of mind as she begins to feel that the quest she's been told they're on, to guide her across the liminal spaces to heavenly safety, is a trap.

In The Ghost Bride, meanwhile, the Plains of the Dead are described as classic wasteland: 'It was so dry that the grass had shrivelled into stalks of dead vegetation, barely covering the crumbling earth like a thin coarse pelt. '(The Ghost Bride, p. 185)

Urban wastelands are always dangerous, and usually abandoned, as in the description of the un-named city in More than This:

Nothing is moving...There are no cars coming down the road...there are no trains. No people...The streets should be full. Front doors should be opening and closing. But there is no-one. (More than This, p. 20) 
In Afterworld, the Necropolis, or City of the Dead, which is one of the main settings of the book, is a partly-ruined city with a threatening atmosphere, blending aspects of Ancient Roman cityscapes, such as gladiatorial arenas, with scenes reminiscent of dystopian urban fantasy settings. In Gary Soto's The Afterlife (2003), the dead narrator Chuy and his ghost friends are still in the suburbs they once lived in, but are no longer at home in them: their familiar places in life have become urban wastelands to them in death.

Settlements in young adult afterlife fiction are generally either absent or small. A notable exception is found in Memor, which predicates a world where how you are remembered by the living determines what kind of afterlife existence you will have. Shifting from the real city of Paris in the living world to an afterworld almost entirely, and unusually, made up of cities set on different planets, it highlights differences between the appearance of the cities as both a clue to and a symbol of the populations found there. So, for instance, the 'Giants', whose memory will live forever, dwell in well-planned cities with tall, beautiful buildings, while the desperate armies of the almost-forgotten live in sprawling slums, creating a systemic atmosphere to this afterworld which reflects a particular aspect of the main character Tomek's quest: the need to understand why memory itself may be threatened in the living world.

Meanwhile, Elsewhere offers an apparently kindly vision of the afterlife, with a setting described as:

a place that looks like almost any other place on Earth. There are buildings, houses, stores, roads, cars, bridges, people, trees, flowers, grass, lakes, rivers, beaches, air, stars and skies...Elsewhere could have been a walk to the next town or an hour's ride in the car or an overnight plane trip. (Elsewhere, p.47)

This is a version of the afterlife as a peaceful, uneventful suburb, yet with an ironic tone, setting the scene for a story that is almost playful in its exploration of the familiar themes of quest and ordeal. The main character Liz's quest-to understand that her purpose is to be 
reborn-takes place in a place that seems, on the surface, to be unthreatening. Yet its bland artificiality and humdrum perfection hides a disconcerting reality whose ramifications only gradually become clear as Liz begins to realise that her previous identity will not only unravel as she ages backwards but that she will also lose all memory of her living history and relationships, in an unstoppable process that at times may even be interpreted as resembling the ordeal of a degenerative brain disorder such as Alzheimer's or dementia. Eventually she will even lose consciousness that it is happening at all.

\section{Real and/or imaginary: a twin atlas}

Most of the afterworlds depicted in the texts are not based on real places or reference them. Two notable exceptions to this, however, are Neal Shusterman's Skinjacker Trilogy, and Yangzse Choo's The Ghost Bride, and it is worth looking at these in some detail to examine the purpose of this blurring of boundaries.

Shusterman's trilogy is perhaps the afterlife fiction that most consciously explores the meaning of place and landscape in the afterlife and its intersection with the living world. Notably, in his vision, every place in the living world may have a 'deadspot' or more-where the dead may safely tread, and which are linked to periods of history, as described in Everwild, the second book in the trilogy:

Nick had never seen a city with so many deadspots. In fact they were so numerous they could hardly be called deadspots at all. The city of Atlanta belonged as much to Everlost as it did to the living world. The streets were part cobblestone, part asphalt, part dirt...Buildings from multiple time periods seemed to occupy the same space, fighting to claim dominant reality. (Everwild, p.41)

Meanwhile, intersections of the worlds are called vortices, as the narrative explains: 
In the varied and multi-layered quilt of creation, one might say that vortices are the points where the surface is attached to the lining. In other words, a vortex is a spot that exists both in Everlost and the living world simultaneously. (Ibid, page 346)

In Shusterman's vision, vortices exist in places where myths have gathered and memories are long, and can appear in surprising places: such as 'The Intolerable Nexus of Extremes' in Memphis--also known as Graceland-- and 'the 'Vortex of the Aggravated Martyr' -also known as the Alamo. There are also cases of buildings that after destruction may cross into Everlost from the living world, appearing there intact, with one example being the Twin Towers in New York, as readers learn in Everlost, the first book in the trilogy:

Such places are few and far between, these grand islands of eternity in the soupy, ever-changing world of the living. New York had its share of foreverplaces. The greatest of these stood near Manhattan's southern-most tip: the two grey brothers to the green statue in the bay. The towers had found their heaven. They were a part of Everlost now, held fast, and held forever by the memories of a mourning world, and by the dignity of the souls who got where they were going on that dark September day. (Everlost, p.64)

Only some 'ghost' buildings from the living world make the journey to Everlost: 'Maybe one out of every thousand that met the wrecking ball was deemed worthy by God, or the universe, or whatever, to cross into Everlost.' (Ibid, p.140) They are an eclectic, even eccentric group, all of which have vanished in the living world, pulled down or destroyed in some way: including, as well as the Twin Towers, an old pickle factory, a small-town diner, the Steel Pier from Atlantic City, and the old Waldorf Astoria Hotel. (Though it is implied that places and buildings from any part of the world may function as 'deadspots' and 'vortices' or re-appear in Everlost after destruction, Shusterman only explicitly references American 
examples in the trilogy.) The purpose of all these 'crossings' in the trilogy is not only to create a setting whose texture is both familiar and jarringly uncanny. It also expresses the liminal, protean nature of the world of Everlost, its places and landscapes. This in turn shapes the equally protean nature of the Afterlights (the dead), especially those who have been in Everlost longest. Another word for protean may be shapeshifting or metamorphic, and in Everlost the place itself acts as a metamorphic force on characters, often literally: for example, the transformation of one of the central characters, Nick, into the 'Chocolate Ogre'; the sudden ability acquired by another central character, Allie, to 'skinjack' or briefly take over living bodies; and the recurring transformations of a significant secondary character, Micky, being amongst the multiple instances of metamorphosis brought about by being in Everlost's shifting landscapes.

Choo's The Ghost Bride also closely explores the relationship between the 'real' Malacca and its 'shadow' version found in the world of the dead; a shadow version which is both within and outside the real city, and is both dependent on it and yet distanced from it. The ghosts cling to this shadow place yet are rendered desperate by it. It is frightening to the main character and narrator, Li Lan, when she first enters the afterlife because it should be familiar and yet is not:

I fled down endless alleyways, plunging through the warren of shops. Hungry ghosts seemed to appear from all directions, detaching themselves from walls and fluttering out of passageways. (The Ghost Bride, p. 110)

In the familiar/unfamiliar streets, transformed by the afterlife, she sees parades of otherworldly beings:

There were tiger-headed men and tiny birds with female faces. Women with backward-pointing feet mingled with lizards dressed in court robes. The walking 
trees and enormous glowing flowers must be the plant spirits and minor deities that Fan had mentioned. (Ibid, p.126)

This shadow-place is a transitional dimension between this life and the afterlife. Later, Li Lan comes through a tunnel into the Plains of the Dead, which is solely occupied by the dead (though it too is a transitional world between the world of the living and the courts of judgement). Her guide, the ghost Fan, tells her that there are settlements across the Plains of the Dead, but set very far apart: 'Towns, villages. They roughly correspond to the places above...But the dwellings come and go as the ghosts move on to the Courts of Judgement. It's always shifting.' (Ibid, 185) It is in this difficult, treacherously transformed terrain that Li Lan's greatest ordeals happen, as she struggles to reach the dead young man to whom she has been promised as a bride by her impecunious father, and plead with him to break the engagement.

The afterworld of The Ghost Bride is inspired by traditional Chinese belief, which included, for instance, an afterlife bureaucracy very similar to that in the living world. For instance, scholars describe how Han funerary documents from the mid-second century BCE record titles of underworld officials such as Lord of the Underworld, Assistant Magistrate of the Underworld and Assistant to the Dead. The documents also contain ordinances such as one against the unjust imposition of taxes by demons, complaints about underworld inefficiencies and recording of rental income earned by the dead. (Shushan and Flood, 2011, p.120)

These kinds of explicit details may serve in traditional belief to give a sense of solidity about what might be expected in the afterlife. But in fiction, their apparent concreteness serves to further disorient the characters: lulled into a sense of false security, they fall into traps more easily than if everything was utterly alien. The ordeal represented by place, which makes the characters' quest towards reconciliation of pre-and post-death realities most potent, urgent and complex, leads to radical change. Liminality, and how this altered, ambiguous inbetween state brings about transformation, as well as what that transformation means to a 
previous sense of psychological integrity and existential identity, is at the heart of young adult afterlife fiction, represented within the protean places of its imagined afterworlds.

\section{References}

Arkinstall, C.(1993) Literature and Quest, Rodopi Perspectives on Modern Literature, Editions Rodopi, Amsterdam.

Bennett, A. (2012) Afterlife and Narrative in Contemporary Fiction, Palgrave Macmillan, London.

Bleeker, G., and Bleeker, B., (2008) 'Literary Landscapes: Using Young Adult Literature to Foster A Sense of Place and Self', The Alan Review, Winter 2008, pages 84-90.

https://scholar.lib.vt.edu/ejournals/ALAN/v35n2/pdf/bleeker.pdf, accessed August 202016

Campbell, P., 'Death and the Afterlife', in Campbell, P. (2015), Spirituality in YA Fiction: The Last Taboo, Rowan and Littlefield Publishers, Lanham, MD.

Carroll, J. S., (2011) Landscape in Children's Literature, Routledge, London.

Catechism of the Catholic Church, Part One, Section Two, Chapter Three, Article 12,

http://www.vatican.va/archive/ccc_css/archive/catechism/p123a12.htm, accessed January 16, 2018.

Choo, Y.,(2013) The Ghost Bride, William Morrow Publishers, New York

Dowell, J. (2012) Interpretations of Joseph Campbell and the Hero's Journey, Michigan State University, https://msu.edu/ jdowell/pdf/JosephCampbellPathHero.pdf , 2012, accessed Dec 202016

Doughty, T., 'Dreaming Into Being: Liminal Spaces in Charles de Lint's young adult mythic fiction', in Doughty, T. and Thompson, D. (2006) Knowing their Place : Identity and Space in Children's Literature, Cambridge Scholars, Newcastle Upon Tyne.

Eaton, A.,(2013) 'From Transition to Threshold, Redefining Young Adulthood', in Write4Children, vol 4 issue 1, June 2013, published by University of Winchester,

http://www.winchester.ac.uk/academicdepartments/EnglishCreativeWritingandAmericanStudies/Documents/ w4cJanvol4iss12013.pdf. Accessed April 12, 2017.

Endsjø, D.O.,(2000) 'To Lock up Eleusis: A Question of Liminal Space', Numen, Vol. 47, No. 4, pp. 351-386,

http://www.jstor.org/stable/3270305 (accessed January 6, 2018)

Kermode, F. (1967) The Sense of an Ending, Oxford University Press, Oxford.

Kriegel, L., (1994) 'Geography Lessons', Sewanee Review, 102.4: 604. https://www.jstor.org/stable/i27546906, Accessed 19 Dec. 2016.

Lanagan, M., (2006) 'Under Heaven, Over Hell', from Red Spikes, Allen and Unwin, Sydney

Lindgren, A.,(1973) The Brothers Lionheart, Oxford University Press, Oxford

Lounsbury, L., (2014) Afterworld, Allen and Unwin, Sydney

Lowe, D. K.,(2016) Postsecular spirituality in Australian YA fiction, Macquarie University, Sydney (thesis)

accessed April 12 2017, http://hdl.handle.net/1959.14/1160088

McFall, C., (2013) Ferryman, Templar Publishing, London

Ness, P., (2013) More than This, Candlewick Press, New York

Nikolajeva, M., (2014) 'Memory of the Present: Empathy and Identity in Young Adult Fiction', Narrative Works, [S.I.], sep. 2014, https://journals.lib.unb.ca/index.php/nw/article/view/22784/26461, Accessed 22 Dec 2016 Nikolajeva, M., (2005) Aesthetic Approaches to Children's Literature: An Introduction, The Scarecrow Press, Lanham, MD.

Shushan, G., and Flood, D., (2011) Conceptions of the Afterlife in Ancient Civilizations, Bloomsbury Publishing, New York. 
Shusterman, N., (2006-2011) The Skinjacker Trilogy: Everlost; Everwild, and Everfound, Simon and Schuster, New York.

Soto, G. (2003) The Afterlife, Houghton Mifflin Harcourt, New York.

Stephens, J., (1992) Language and Ideology in Children's Fiction, Longman, Harlow.

Turner, V., (1967) The Forest of Symbols, Cornell University Press, Ithaca, New York.

Welty, E. (1955) 'Place in Fiction, 'Collected Essays, http://xroads.virginia.edu/ drbr/welty.txt, Accessed 19 Dec 2016.

Wyrzykowska, K.(2015), Memor : le monde d'après, Bayard Editions, Paris.

Zevin, G. (2007) Elsewhere, Square Fish, New York.

\section{Biographical Note}

Born in Indonesia of French parents, and brought up in France and Australia, Sophie Masson is the awardwinning and internationally-published author of over 60 books for children, young adults and adults. Her latest books include Jack of Spades, a young adult thriller (2017), as well as several picture books, See Monkey(2018), Once Upon An ABC, Two Rainbows, and Building Site Zoo, all published in 2017. Forthcoming in 2019 are a historical novel for middle-grade readers, War and Resistance(Scholastic Australia) as well as three picture books.

She recently completed her PHD in Creative Practice at the University of New England in Australia, where she has been working on the creation of a young adult speculative fiction novel, The Ghost Squad, with an accompanying exegesis examining the cultural, philosophical and narrative context of contemporary young adult afterlife fiction. She has presented her research work at conferences and her scholarly articles on afterlife fiction and other literary and writing topics have been published in journals including TEXT, M/C Journal, The Looking Glass, Bookbird, and New Writing. 